\title{
Influence of Geometric Parameters on the Thermal Performances of a Double Air Pass Solar Collector
}

\author{
Abraham Tetang Fokone ${ }^{1,2, *}$, Adrian-Gabriel Ghiaus ${ }^{2}$ \\ ${ }^{1}$ Laboratory of Energetic and Thermal Applied, ENSAI/University of Ngaoundere, Ngaoundere, Cameroon \\ ${ }^{2}$ Doctoral School, Technical University of Civil Engineering of Bucharest, Bucharest, Romania
}

Email address:

abramtetang@yahoo.fr (Abraham T. F.), ghiaus@yahoo.com (Adrian-Gabriel G.)

${ }^{*}$ Corresponding author

\section{To cite this article:}

Abraham Tetang Fokone, Adrian-Gabriel Ghiaus. Influence of Geometric Parameters on the Thermal Performances of a Double Air Pass Solar Collector. Science Journal of Energy Engineering. Vol. 7, No. 4, 2019, pp. 67-76. doi: 10.11648/j.sjee.20190704.13

Received: September 20, 2019; Accepted: October 17, 2019; Published: October 28, 2019

\begin{abstract}
This work focused on the numerical study of the thermal performance of a solar collector in order to improve the indirect solar drying of fruit in an environment with high solar potential. It aims to contribute to the reduction of post-harvest losses observed during periods of high production. From the retained physical model, an equivalent electrical scheme has been established and energy balance was applied to each slice of the model using the nodal method. The obtained different equations were discretized using the implicit method of finite differences, and solved by the iterative Gaussian Pivot method written in FORTRAN program. The obtained results showed that, from April to June (mangoes harvest period in Ngaoundere city) the raining period in Adamawa Region, the solar air collector that length to width ratio is between 2 and 3, is sufficient to carry out indirect solar drying of fruits with forced convection. The outlet air temperature of the solar collector was between 45 and $60^{\circ} \mathrm{C}$ with an average value of $50^{\circ} \mathrm{C}$, and the thermal efficiency was between 65 and $95 \%$ with an average value of $80 \%$. Double glazing improves efficiency of the solar air collector for a small footprint.
\end{abstract}

Keywords: Thermal Performance, Solar Collector, Unidirectional Flow, Double Air Pass, Modeling

\section{Introduction}

Solar energy is the most significant source of the renewable energy on the planet. The quantity of this energy flux reaching the earth's surface, i.e. $1.76 .10^{17} \mathrm{~W}$, is today largely higher than the total power consumption [1]. One of the simple and direct applications of this natural and free energy is the conversion of the solar irradiation into heat, which can be used either for solar heating of building, solar refrigeration, industrial processes, and the solar collector. In this last case, conversion is done using the collectors, with the aim of heating water or air for domestic uses [2] and industrial applications $[3,4]$. It can also be employed for the drying of the agricultural produce. Solar collectors can also be employed for the drying of agricultural produce.

In fact, several research tasks undertaken in this field, have for the majority, license to conceive and carry out solar systems of air drying with plan solar collectors as in Malaysia for the drying of hot red pepper [5]. For the countries in the process of development which produce more than $80 \%$ of food [6], the use of the solar collector for drying is not enough widespread. In the wet tropical zone, the production of the exotic fruits occupies today roughly $75 \%$ of the production of the world of the fresh tropical fruits [7]. However, the major part of this production is lost after the harvest periods, because of the insufficiency and even the absence of the conservation and treatment systems for these fruits on the harvest sites. In sub-Saharan Africa, these losses are estimated at more than $40 \%$ [8]. Particularly, in Cameroon, the average solar irradiation is $4.9 \mathrm{kWh} / \mathrm{m}^{2} . \mathrm{d}$, and this solar potential is sufficient for the development of the conversion systems of solar energy [9, 10], like the solar driers for example. Thus opposite to the question of knowing how to reduce the post-harvest losses, by minimizing the power consumption, we choose with the modeling of a plane air solar collector. Knowing that the solar collectors have a low thermal effectiveness (roughly $36 \%$ ), it is thus a question of seeing how to optimize their construction in order to increase the thermal efficiency. 
Solar collectors have already made the subject of many numerical and experimental studies. They exist under two principal configurations: concentrators and plane collectors. The latter, being able to use water or the air as thermal agent, are present in several research tasks [11-17], which relate to the optimization of the thermal effectiveness. The reduction of post-harvest losses can be obtained by using a modular solar drier, for which the air is preheated by the solar collectors. Thus there are several configurations of the plane solar collector with air, such as single glazing and double glazing with single pass or double passes.Preliminary studies have found that for a double glazing collector, the useful heat flux is greater than that of a single glazing unit [7, 18]. It follows that the outlet temperature of the fluid of a double glazing collector is higher than that of the single-glazed collector. The present work concerns a unidirectional air solar collector double passes and glazing. In our study, the modeling of the plane solar collector with air with forced convection was carried out by using the method of Hottel, Whillier and Bliss [13]. It will be in the remainder to do the modeling effect of geometric parameters on the thermal performances of a unidirectional air collector double passes and glazing generally, and in a particular case, find an optimal surface of collector for drying fruits in a west tropical region.

\section{Materials and Methods}

\subsection{Physical and Analogical Model}

The studied air solar collector has two glasses, upper glass (3) and lower glass (5) as cover, an absorber plate (7) and an insulating material (9). The two glasses are separated by an air layer (4) that promotes the greenhouse effect. The air used as thermal agent, circulates inside the collector through two passages, (6) and (8), separated by the absorber (7). The two air flows enter the collector on the same side and go out on the opposite one. The solar radiation crosses the sky (1) and the earth's atmosphere (2) before reaching the collector surface. The collector, placed on the ground (10), can be inclined relative to the horizontal angle $\beta$ in order to increase the capture of solar radiation during the day (figure 1).

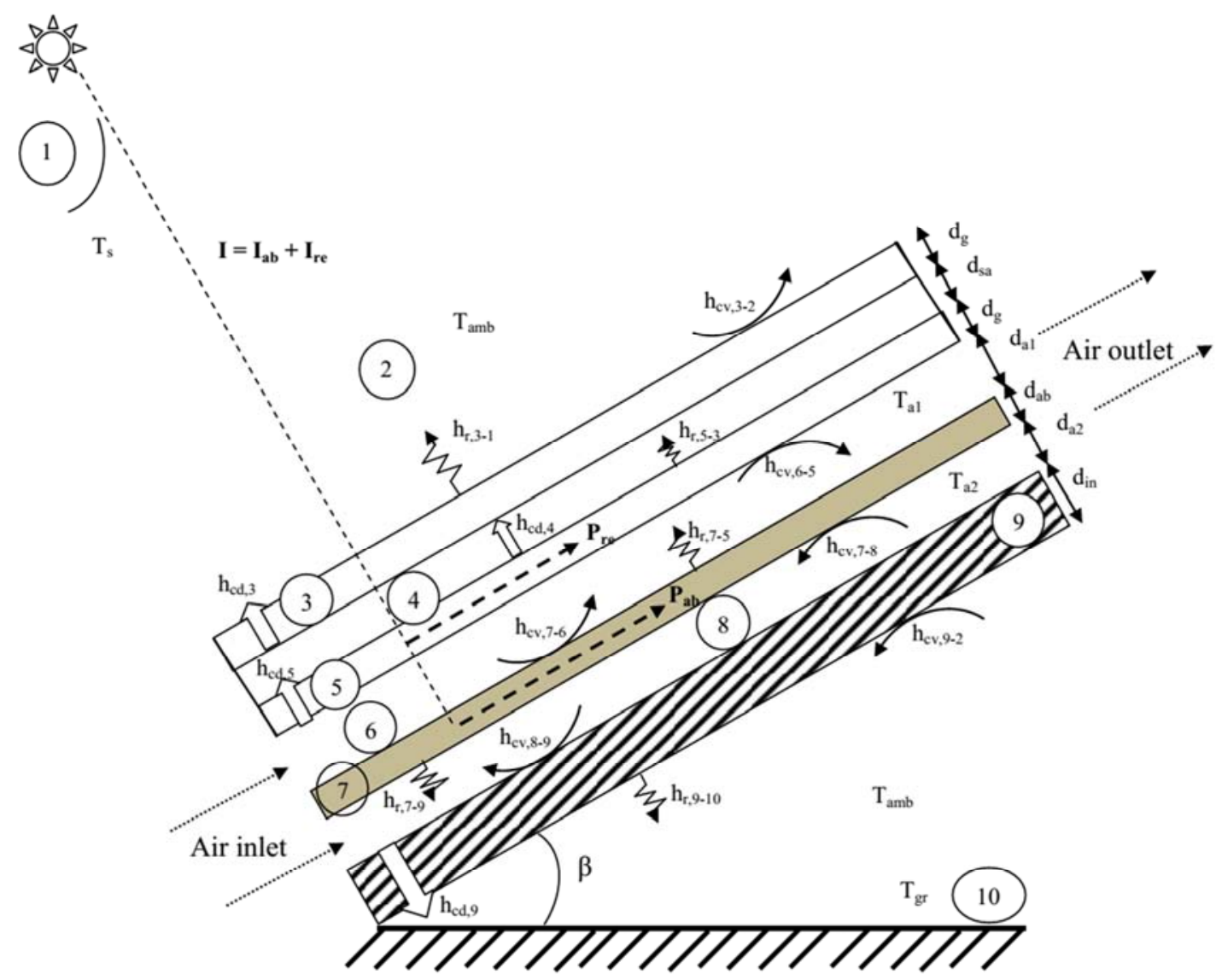

Figure 1. Air collector double glazing and double passes, $\Rightarrow$ heat exchange by conduction, $\rightarrow$ heat exchange by convection, $\rightarrow$ heat exchange by radiation, - - - solar radiation.

By analyzing the heat transfers within a section of the air solar collector (figure 1), the equivalent electrical circuit for the thermo-electrical analogy is represented in figure 2 by using the following analogies [19]:

Heat flux density $\approx$ intensity of electric current Temperature $\approx$ electric potential

Heat transfer coefficient $\approx$ conductance

Heat capacity $\approx$ electric capacity 


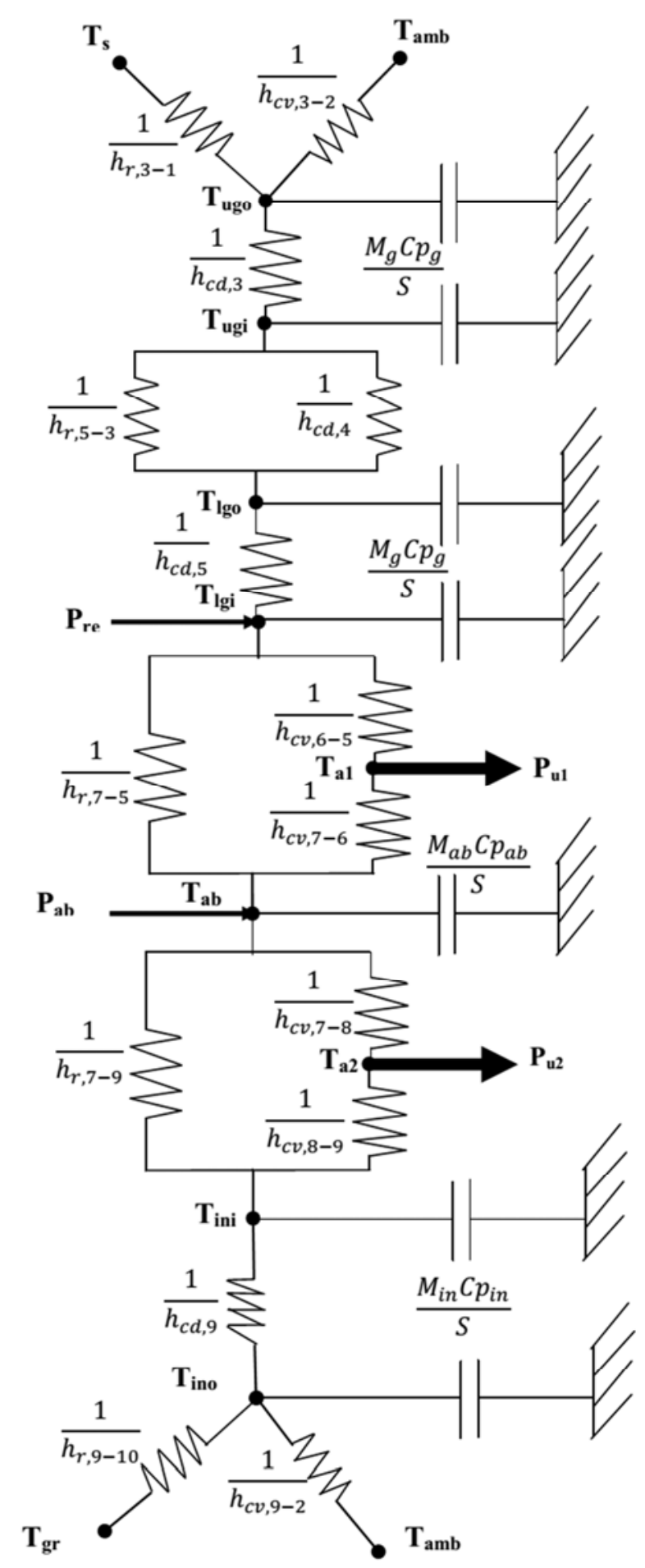

Figure 2. Equivalent electrical circuit for the thermo-electrical analogy of solar collector. node; $-\downarrow$ Heat capacity; thermal resistance; transfer reference; $h_{\mathrm{r}, 3-1}$ : radiation coefficient between the sky and the outside upper glass; $h_{\mathrm{cv}, 3-2}$ : convection coefficient between the ambient and the outside upper glass; $\mathrm{h}_{\mathrm{cd}, 3}$ : conduction coefficient in the upper glass; $h_{r, 5-3}$ : radiation coefficient between the inside upper glass and outside lower glass; $h_{c d 4}$ : conduction coefficient in the still air blade; $h_{c d, 5}$ : conduction coefficient in the lower glass; $h_{\mathrm{cv}, 6-5}$ : convection coefficient between the air in passage 1 and the inside lower glass; $\mathrm{h}_{\mathrm{cv}, 7-6}$ : convection coefficient between the air in passage 1 and the absorber; $h_{r, 7-5}$ : radiation coefficient between the inside lower glass and the absorber; $h_{r, 7-9}$ : radiation coefficient between the absorber and the inside of insulting material; $h_{c v 7-8}$ : convection coefficient between the air in passage 22 and the absorber; $\mathrm{h}_{\mathrm{cv}, 8-9}$ : convection coefficient between the air in passage 2 and the inside of insulting material; $\mathrm{h}_{\mathrm{cd}, 5}$ : conduction coefficient in the insulting material; $h_{\mathrm{cv}, 9-2}$ : convection coefficient between the ambient and the outside insulting material; $h_{r, 9-10}$ : radiation coefficient between the outside insulting material and the ground.

\subsection{Mathematical Modelling and Numerical Simulation}

In order, to model the heat transfer inside the collector, the following assumptions were made: heat flux is unidirectional; the collector is divided along its length (in the air flow direction) in sections of $\Delta x$ thickness; the physical properties of the materials do not depend on temperature; the air velocity is constant and the sky is considered black body.

Taking into account the above assumptions, the depending variables of the model are: $\mathrm{T}_{\mathrm{ugo}}$ : outside upper glass temperature $(\mathrm{K}) ; \mathrm{T}_{\text {ugi }}$ : inside upper glass temperature $(\mathrm{K})$; $\mathrm{T}_{\text {lgo }}$ : outside lower glass temperature $(\mathrm{K}) ; \mathrm{T}_{\text {lgi }}$ : inside lower glass temperature $(\mathrm{K}) ; \mathrm{T}_{\mathrm{ab}}$ : absorber temperature $(\mathrm{K}) ; \mathrm{T}_{\text {ini }}$ : inside insulting material temperature $(\mathrm{K}) ; \mathrm{T}_{\text {ino }}$ : outside insulting material temperature $(\mathrm{K}) ; \mathrm{P}_{\mathrm{u} 1}$ : useful power of air in passage $1(\mathrm{~W}) ; \mathrm{P}_{\mathrm{u} 2}$ : useful power of air in passage $2(\mathrm{~W})$.

In the equivalent electrical circuit of figure 2 , each node represents a part of the air solar collector symbolized by its temperature. On this schema, the thermal resistances, the heat capacities, and the thermal losses were also represented.

The equation system governing the heat transfers on each node of the collector are obtained from thermal balances carried out as follows:

Upper glass

Outside face

$$
\frac{M_{g} * C p_{g}}{S}\left(\frac{\partial T_{u g o}}{\partial t}\right)=h_{c v, 3-2}\left(T_{a m b}-T_{u g o}\right)+h_{r, 3-1}\left(T_{s}-T_{u g o}\right)+h_{c d, 3}\left(T_{u g i}-T_{u g o}\right)
$$

Inside face

$$
\frac{M_{g * C p_{g}}}{S}\left(\frac{\partial T_{u g i}}{\partial t}\right)=\left[h_{c d, 4}+h_{r, 5-3}\right]\left(T_{l g o}-T_{u g i}\right)+h_{c d, 3}\left(T_{u g o}-T_{u g i}\right)
$$

Lower glass

Outside face 


$$
\frac{M_{g * C p_{g}}}{S}\left(\frac{\partial T_{l g o}}{\partial t}\right)=\left[h_{c d, 4}+h_{r, 5-3}\right]\left(T_{u g i}-T_{l g o}\right)+h_{c d 5}\left(T_{l g i}-T_{l g o}\right)
$$

Inside face

$$
\frac{M_{g} * C p_{g}}{S}\left(\frac{\partial T_{l g i}}{\partial t}\right)=h_{c v, 6-5}\left(T_{a 1}-T_{l g i}\right)+h_{r, 7-5}\left(T_{a b}-T_{l g i}\right)+h_{c d 5}\left(T_{l g o}-T_{l g i}\right)+P_{r e}
$$

Absorber

$$
\frac{M_{a b} * C p_{a b}}{S}\left(\frac{\partial T_{a b}}{\partial t}\right)=P_{a b}+h_{c v, 7-6}\left(T_{a 1}-T_{a b}\right)+h_{r, 7-5}\left(T_{l g i}-T_{a b}\right)+h_{c v, 7-8}\left(T_{a 2}-T_{a b}\right)+h_{r, 7-9}\left(T_{i n i}-T_{a b}\right)
$$

Insulating material

Inside face

$$
\frac{M_{i n} * C p_{i n}}{S}\left(\frac{\partial T_{i n i}}{\partial t}\right)=h_{c v, 8-9}\left(T_{a 2}-T_{i n i}\right)+h_{r, 7-9}\left(T_{a b}-T_{i n i}\right)+h_{c d, 9}\left(T_{i n o}-T_{i n i}\right)
$$

Outside face

$$
\frac{M_{\text {in }} * C p_{\text {in }}}{S}\left(\frac{\partial T_{\text {ino }}}{\partial t}\right)=h_{c v, 9-2}\left(T_{a m b}-T_{\text {ino }}\right)+h_{r, 9-10}\left(T_{g r}-T_{\text {ino }}\right)+h_{c d, 9}\left(T_{\text {ini }}-T_{\text {ino }}\right)
$$

Air flow

Air in passage 1

$$
\begin{gathered}
\frac{M_{a * C p_{a}}}{S}\left(\frac{\partial T_{a 1}}{\partial t}\right)+P_{u 1}=h_{c v, 6-5}\left(T_{a b}+T_{l g i}-2 * T_{a 1}\right)(8) \\
P_{u 1}=U_{a 1} \frac{M_{a} * C p_{a}}{S} \frac{\partial T_{a 1}}{\partial x}
\end{gathered}
$$

Air in passage 2

$$
\begin{gathered}
\frac{M_{a * C p_{a}}}{S}\left(\frac{\partial T_{a 2}}{\partial t}\right)+P_{u 2}=h_{c v, 7-8}\left(T_{a b}+T_{i n i}-2 * T_{a 2}\right)(9) \\
P_{u 2}=U_{a 2} \frac{M_{a} * C p_{a}}{S} \frac{\partial T_{a 2}}{\partial x}
\end{gathered}
$$

out by using the thermo physical properties of the air shown in Table 1 and the thickness of different materials of collector presented on Table 2. The energy balances between time $t$ and $\mathrm{t}+\Delta \mathrm{t}$ were obtained by writing the flux balances relating to the nodes of the schema of figure 2. Transfer equations are solved using an implicit numerical scheme, Gauss algorithm and an iterative procedure. This iterative procedure is necessary because the convection and radiation coefficients are depending on the materials temperatures, which are

\begin{tabular}{|c|c|c|c|c|c|}
\hline$d_{g}(m)$ & $d_{\mathrm{sa}}(\mathrm{m})$ & $\mathrm{d}_{\mathrm{a} 1}(\mathrm{~m})$ & $\mathrm{d}_{\mathrm{ab}}(\mathrm{m})$ & $\mathrm{d}_{\mathrm{a} 2}(\mathrm{~m})$ & $\mathrm{d}_{\mathrm{in}}(\mathrm{m})$ \\
\hline $3.10^{-3}$ & $5.10^{-3}$ & $2.510^{-2}$ & $6.10^{-4}$ & $2.510^{-2}$ & $2.510^{-2}$ \\
\hline
\end{tabular}
unknowns. The different steps of the numerical modeling are given in figure 3 .

The determination of the heat transfers parameters is presented in Appendix 1.

The simulation of collector thermal behavior was carried

Table 1. Thermophysical properties of air [19, 20].

\begin{tabular}{ll}
\hline Velocity & $\mathbf{1 . 5} \mathbf{~ m} / \mathbf{s}$ \\
\hline Specific heat & $C p_{a}=1005.7+6.6 \cdot 10^{-2}\left(T_{a}-300.15\right)$ \\
Density & $\rho_{a}=1.177-3.59 \cdot 10^{-3}\left(T_{a}-300.15\right)$ \\
Dynamic viscosity & $\mu_{a}=\left[1.983+1.84 \cdot 10^{-3}\left(T_{a}-300.15\right)\right] \cdot 10^{-5}$ \\
Thermal conductivity & $\lambda_{a}=26.24 \cdot 10^{-3}+7.58 \cdot 10^{-5}\left(T_{a}-300.15\right)$ \\
\hline
\end{tabular}

Table 2. Thickness of different materials of collector.

The input power is given by [21]:

$$
P_{a b}=\alpha_{a b} . S . I_{a b}
$$

Where $\alpha_{\mathrm{ab}}=1 ; \mathrm{I}_{\mathrm{ab}}$ : global solar radiation incident received by absorber; $\mathrm{S}=\mathrm{L}$. w (L, w are length and width of collector respectively).

The output power, $\mathrm{P}_{\mathrm{u}, \mathrm{i}}$ represents the heat flux received by the working fluid. It is calculated by Ricci et al., [21]:

$$
P_{u, i}=\dot{m} C p_{a, i}\left(T_{a, i}-T_{a m b}\right)
$$

where $\dot{m}$ is the air flow $(\mathrm{kg} / \mathrm{s})$.

The collector efficiency was calculated as the ratio of the output power and the input power (solar flux density) [21]:

$$
\eta=\frac{P_{u}}{P_{a b}}
$$

\subsection{Modelling of the Ambient Temperature}

The ambient temperature evolution during a day is modeled using the following expression [22]: 


$$
\mathrm{T}_{\mathrm{amb}}=\mathrm{T}_{1}+\mathrm{T}_{2} \cdot \cos \left[\frac{\pi}{12} \cdot(14-\mathrm{TSV})\right]
$$

where

$$
\begin{aligned}
\mathrm{T}_{1} & =\frac{\mathrm{T}_{\mathrm{amb}-\max }+\mathrm{T}_{\mathrm{amb}-\min }}{2} \\
\mathrm{~T}_{2} & =\frac{\mathrm{T}_{\mathrm{amb}-\max }-\mathrm{T}_{\mathrm{amb}-\min }}{2}
\end{aligned}
$$

with $\mathrm{T}_{\mathrm{amb}-\max }$ and $\mathrm{T}_{\mathrm{amb}-\mathrm{min}}$ the maximum and minimum ambient temperature during each day $\left({ }^{\circ} \mathrm{C}\right)$.

The total, direct and diffuse solar irradiations for Ngaoundere (Cameroon), received by the air solar collector are computed during the typical days, using meteorological data of the Capital of Adamawa's Region (732N; 1358E).

\subsection{Modelling of the Solar Radiation}

The incident solar radiation depends on several geographical magnitudes such as the latitude and the longitude of the location where the collector is placed. As part of this work, these calculations were done for the city of Ngaoundere in Cameroon (see Appendix 2).

\subsection{Numerical Resolution}

Equations (1) to (9) are discretized by the implicit finite difference method, and the final system can be in the form of a matrix $(9 \times 9)$ as follows:

$$
A * T=B
$$

The matrix defined by equation (14) was solved by the following algorithm presented in figure 3 .

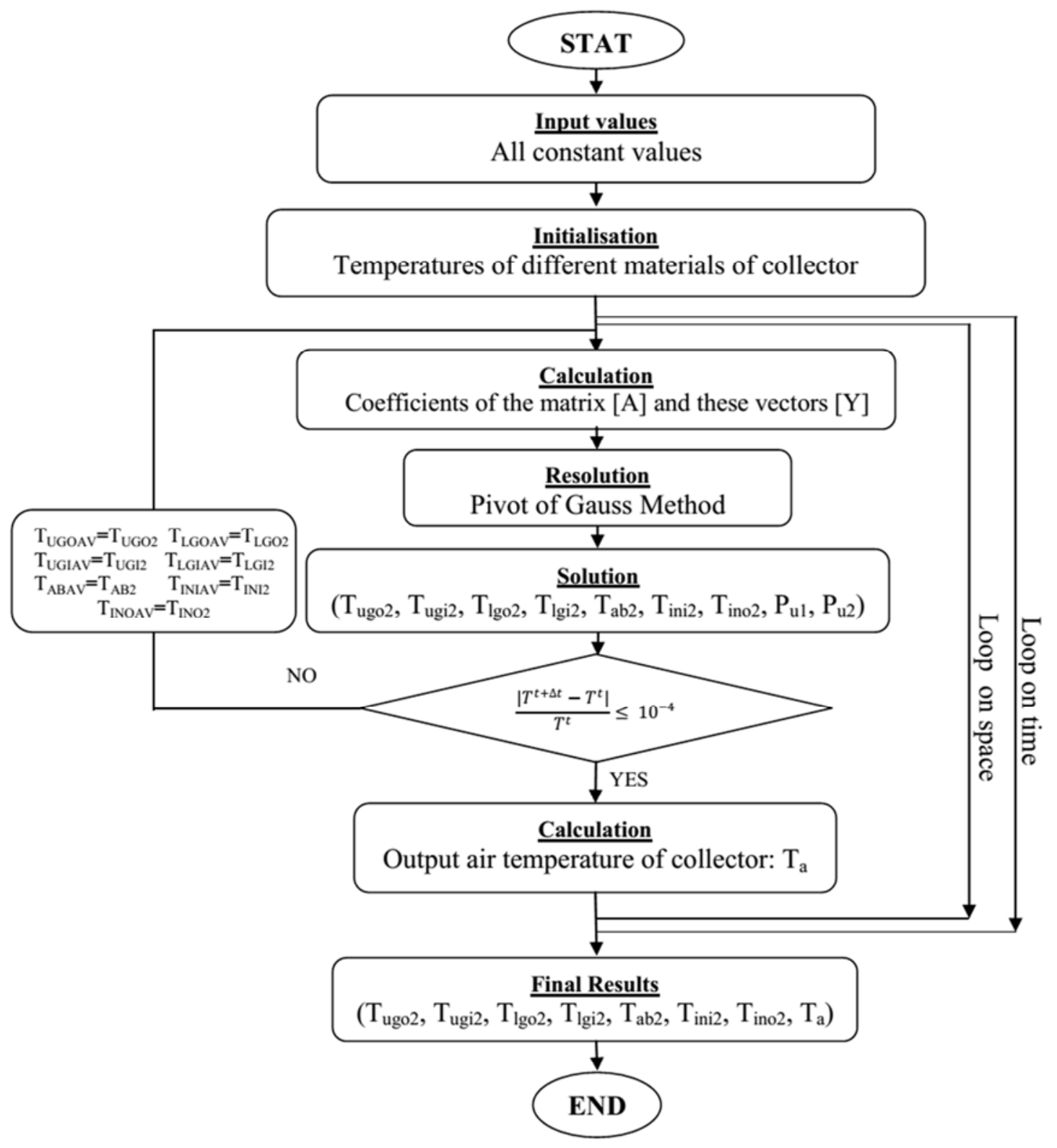

Figure 3. Algorithm of numerical modeling of air solar collector double passes and glazing. 


\section{Results and Discussion}

\subsection{Solar Radiation}

Simulation of the solar radiation of the town of Ngaoundere in the Adamawa's Region during a whole year is presented in figures 4 and 5 .

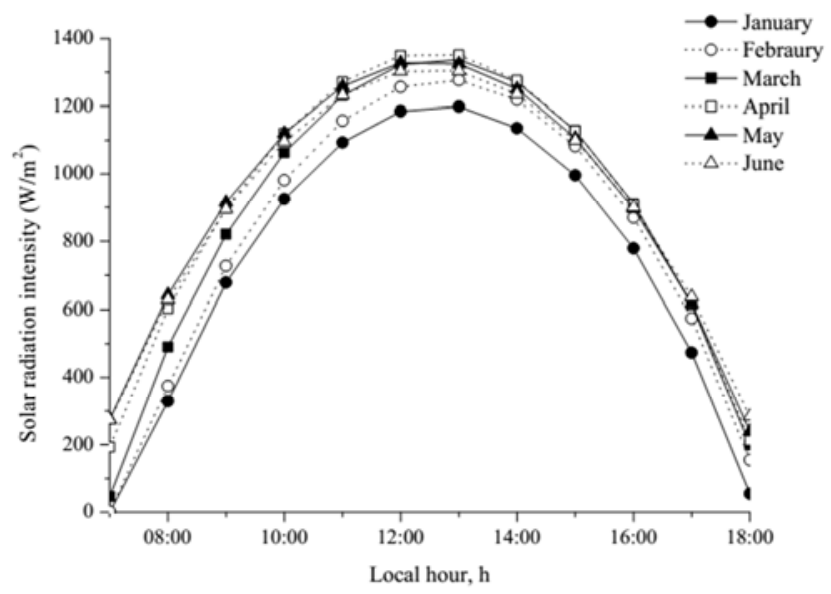

Figure 4. Solar radiation during the first sixth months of the year.

During the first half of the year, the city of Ngaoundere receives its lowest radiation during the month of January (figure 4). Its maximum value is $1100 \mathrm{~W} / \mathrm{m}^{2}$ at $1 \mathrm{p} . \mathrm{m}$ local time $(\mathrm{GMT}+1)$. This maximum irradiation is $1300 \mathrm{~W} / \mathrm{m}^{2}$ during the months of March and April when the town is very sunny.

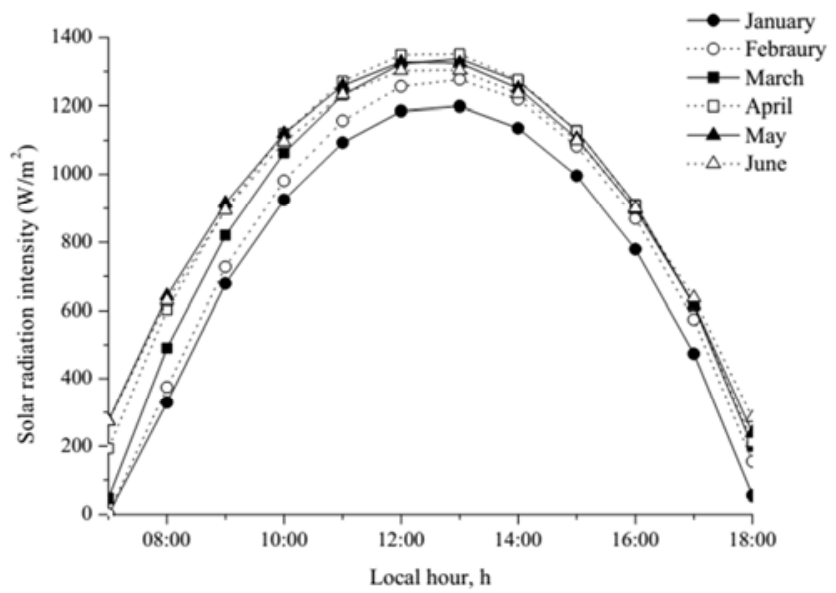

Figure 5. Solar radiation during the second sixth months of the year.

The months of November and December are the periods of low sunshine in the town of Ngaoundere during the second half of the year (figure 5).

These simulation results are in good agreement with those of Laux et al., who showed that, using the meteorological data of Cameroon, the solar irradiation in the Adamawa region is in a range of 1200 to $1500 \mathrm{~W} / \mathrm{m}^{2}$ [23].

\subsection{Influence of Geometrical Characteristics}

The increase of the length to width ratio leads to an increase in the outlet air temperature of the solar collector. The month of March is the period of year in Ngaoundere when the outlet air temperature reaches the highest values (figure 6).

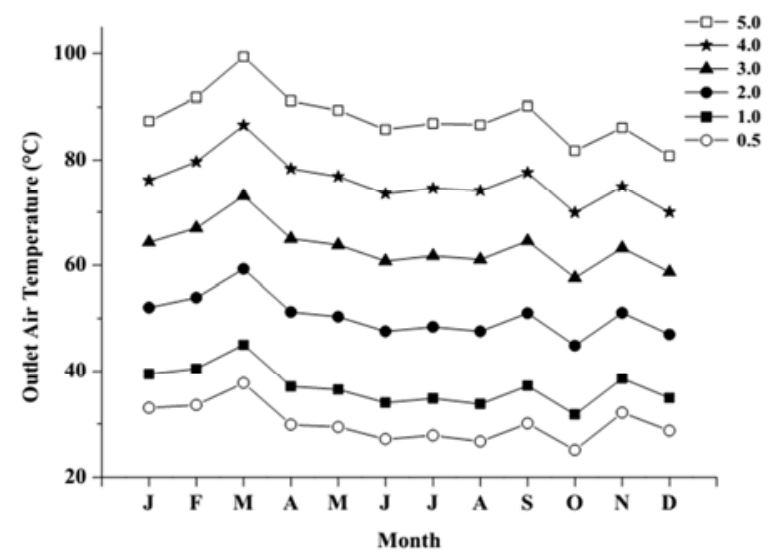

Figure 6. Simulation results of outlet air temperature of collector for different length to width ratio $(L / w)$ in Ngaoundere.

For the length to width ratio $\mathrm{L} / \mathrm{w}=2$, the average outlet temperature of the solar collector during the whole year is $50^{\circ} \mathrm{C}$ (figure 6), and hence for a greater length to width ratio (L/w $\geq 2)$, a unidirectional air solar collector double passes and double glazing can, in general, assure drying of fruits and vegetables especially in the town of Ngaoundere.

Since Ngaoundere is conducive to the production of mangoes during the periods from April to June, for indirect solar drying during this period, a solar collector double glazing and double passes with $\mathrm{L} / \mathrm{w}=3$ would be sufficient to ensure a maximum temperature of $60^{\circ} \mathrm{C}$ (figure 6).

For the month of March which corresponds to the sunniest period of the year in the city of Ngaoundere, the outlet air temperature of the solar collector can be expressed by a linear function of the length to width ratio:

$$
T_{\text {air, average }}=13.730 \frac{L}{w}+31.365
$$

with $\mathrm{R}^{2}=0.999$.

The efficiency of the solar collector decreases as the length to width increases (figure 7). In this figure, the best efficiency is above $90 \%$ for the months of February, March, July and August in the town of Ngaoundere. Even with a length to width ratio $\mathrm{L} / \mathrm{w}=5$, the efficiency of a unidirectional air solar collector double passes and double glazing is always higher than for a single glazing collector which is around $45 \%$. The lowest efficiency is $63 \%$, obtained for the month of November.

The influence of the outlet temperature of the collector on its performance for the month of March is presented in figure 8.

This is a linear regression where the efficiency is inversely proportional to the outlet temperature. The optimum 
operating value is for the length to width ratio between 2 and $3(2 \leq \mathrm{L} / \mathrm{W} \leq 3)$.

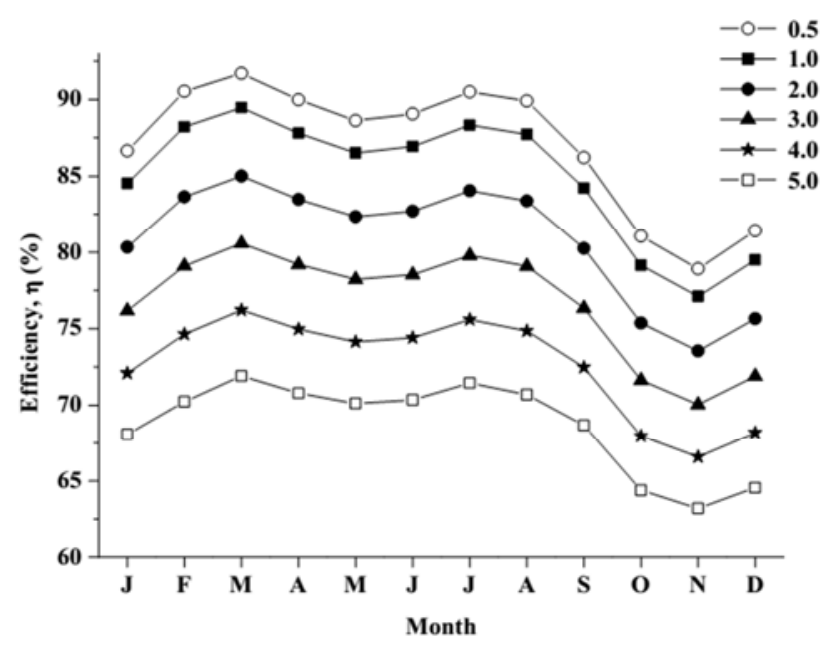

Figure 7. Simulation results of efficiency of collector for different length to width ratio (L/w) in Ngaoundere.

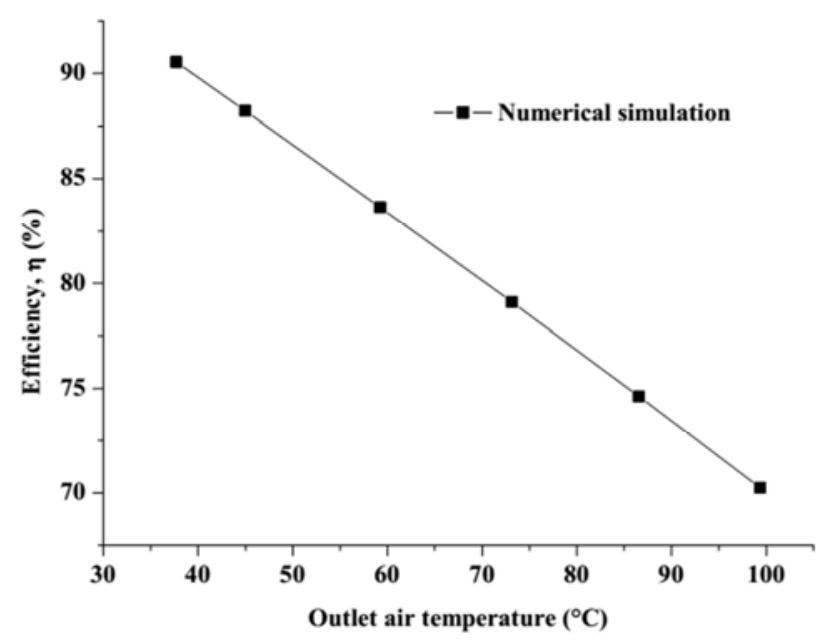

Figure 8. Effect of outlet air temperature on the efficiency of the air solar collector during the month of March.

The solar collector efficiency can be approximated by linear function of average air temperature:

$$
\eta=-0.00329 . T_{\text {air,average }}+1.03032
$$

with $\mathrm{R}^{2}=0.999$, and the average air temperature calculated as:

$$
T_{\text {air , average }}=\frac{\dot{m}_{\text {air } 1} \cdot T_{\text {air } 1}+\dot{m}_{\text {air } 2} \cdot T_{\text {air } 2}}{\dot{m}_{\text {air } 1}+\dot{m}_{\text {air } 2}}
$$

Considering equation (19), the collector efficiency can be expressed as:

$$
\eta=-0.0452 \cdot \frac{L}{w}+0.927
$$

with $\mathrm{R}^{2}=0.999$.

\subsection{Analysis of Temperature Profiles}

Daily temperature evolution for different layers of air solar collector was simulated for the length to width ratio $\mathrm{L} / \mathrm{w}=2$; $\mathrm{L}=1 \mathrm{~m} ; \mathrm{w}=0.5 \mathrm{~m}$ and $\mathrm{S}=0.5 \mathrm{~m}^{2}$.

The temperature profile of the different layers of the collector, during the month of April, which is the beginning of harvest of mangoes in the city of Ngaoundere is presented in figure 9 .

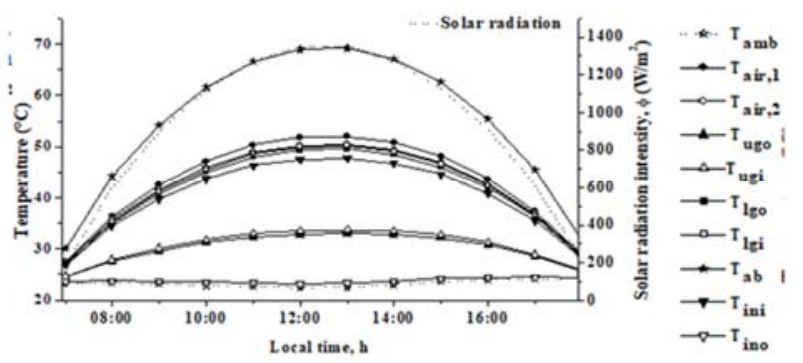

Figure 9. Numerical simulation results of nodes temperature of air solar collector.

The temperature profiles of the external insulating material and the ambient are almost similar, as those of the out and inside faces of the upper glass (figure 9). This shows that heat losses at the back of the collector are almost zero, but these are important at the front. The absorber is the layer with the highest temperature throughout the day. The heat captured by the absorber is mainly transported by air in passage 1 and 2, and the remainder is transfered to the lower glass and the inside of the insulting material. This analysis is justified by the observed proximity between the following 5 temperatures $\left(\mathrm{T}_{\text {air } 1}, \mathrm{~T}_{\text {air } 2}, \mathrm{~T}_{\text {lgo }}, \mathrm{T}_{\text {lgi }}\right.$ and $\left.\mathrm{T}_{\text {ini }}\right)$. The similar results were obtained by Kareem et al., [24].

\subsection{Validation}

The figure 10 shows that the outlet air temperature computed is close to the experimental one made by Tetang [25].

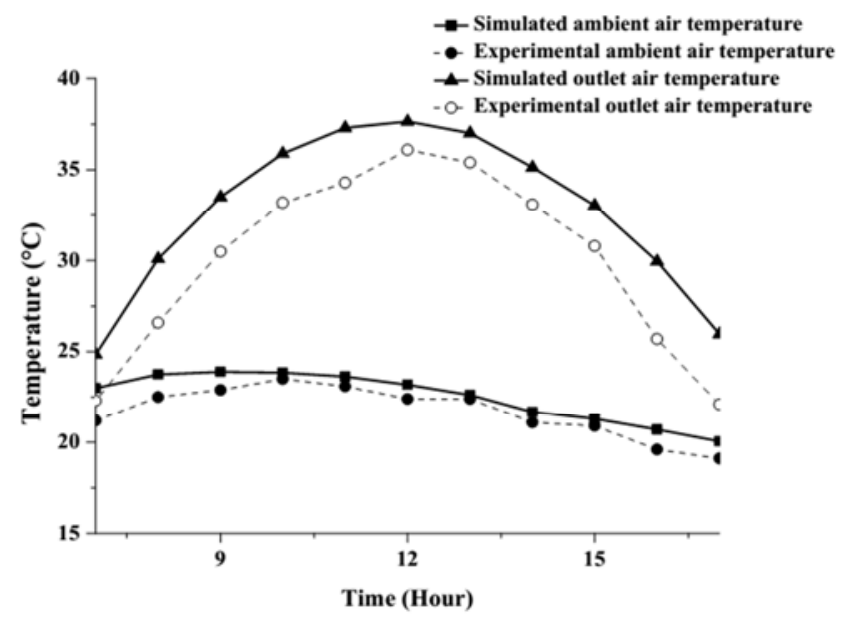

Figure 10. Evolution of inlet and outlet air temperature of an air plane solar collector. 
As it can be noted in figure 10 the experimental and numerical evolution during the day of the outlet air temperature of the solar collector is described by a parabola. The maximum value of $35^{\circ} \mathrm{C}$ is reached at $12 \mathrm{a} . \mathrm{m}$. Indeed, the discrepancies between the numerical and experimental results reach $8 \%$ for the ambient air temperature, and $14.90 \%$ for the outlet air temperature.

The figure 11 presents the experimental thermal efficiency evolution.

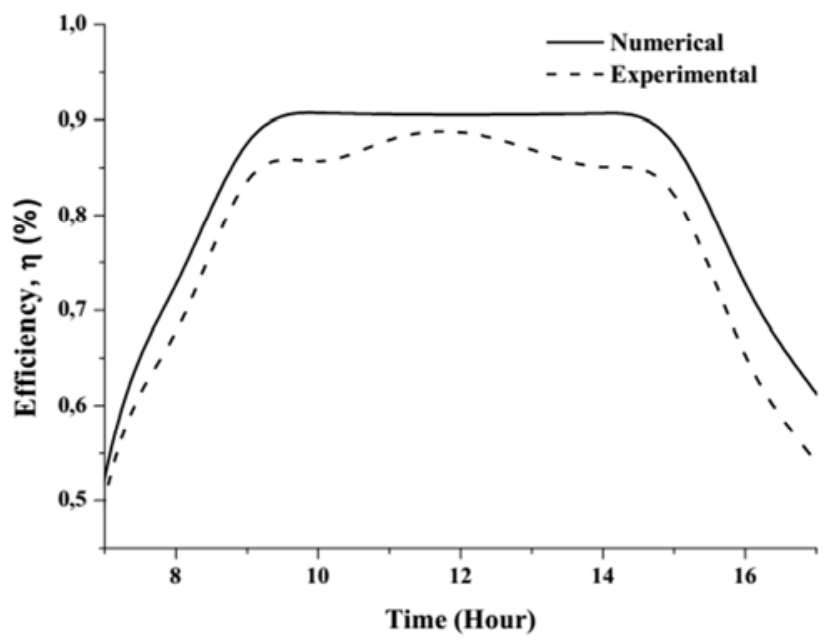

Figure 11. Experimental thermal efficiency of an air plane solar collector double glazing and double pass.

The thermal efficiency is superior to $50 \%$. These results show that the solar collector double glazing and double pass conducts to a thermal efficiency superior to the one of an air plane solar collector simple pass, or single glazing. Our results are close to those of Ihaddadene et al., [14] and
Nikolić et al., [16]. Results reported by theses authors show that the thermal efficiency of an air plane solar collector double glazing is above $45 \%$. We note that the maximal discrepancies observed between the numerical and experimental results reached $7.05 \%$.

\section{Conclusion}

The present work focused on numerical modeling of the thermal behavior of an unidirectional air solar collector double passes and double glazing, for the drying of fruits in the city of Ngaoundere. The energy balances applied to the different nodes of the equivalent electrical circuit led to the writing of a system of equations that was solved through the iterative Gaussian Pivot method. The main results obtained showed that during the period from April to June, period of harvest of mangoes in the city of Ngaoundere, a collector double passes and double glazing having a length to width ratio between 2 and $3(2 \leq \mathrm{L} / \mathrm{w} \leq 3)$, is sufficient to perform indirect solar drying of fruits during the daylight. The average outlet air temperature is $50^{\circ} \mathrm{C}$ with efficiency greater than $80 \%$. Therefore, the length to width ratio as well as the exchange surface has a significant influence on the air outlet temperature and the efficiency of the solar collector.

\section{Acknowledgements}

This research was supported by the Romanian Ministry of Foreign Affairs in collaboration with Agence Universitaire de la Francophonie (AUF) in the framework of "Eugen Ionescu" Program.

\section{Nomenclature}

$\begin{array}{ll}\Delta \mathrm{x} & \text { section length } \\ \mathrm{Cp} & \text { specific heat } \\ \text { d } & \text { depth of air between upper and lower glasses } \\ \mathrm{d}_{1} & \text { depth of air of upper passage } \\ \mathrm{d}_{2} & \text { depth of air of lower passage } \\ \text { DH } & \text { hydraulic diameter } \\ \mathrm{F} & \text { form factor } \\ \text { h } & \text { heat transfer coefficient } \\ \text { I } & \text { global solar radiation incident on horizontal surface } \\ \text { L } & \text { length of collector } \\ \mathrm{M} & \text { equivalent section mass } \\ \mathrm{P} & \text { thermal power } \\ \mathrm{S} & \text { collector surface area } \\ \text { T } & \text { temperature } \\ \text { U } & \text { air velocity } \\ \text { V } & \text { wind velocity } \\ \text { W } & \text { width of collector } \\ \text { Greek symbols } \\ \alpha & \text { absorption coefficient } \\ \sigma & \text { Stephan-Boltzmann constant } \\ \beta & \text { collector slope angle } \\ \varphi & \text { heat flux density }\end{array}$

$\mathrm{m}$
$\mathrm{J} / \mathrm{K} \mathrm{kg}$
$\mathrm{m}$
$\mathrm{m}$
$\mathrm{m}$
$\mathrm{m}$
-
$\mathrm{W} / \mathrm{K} \mathrm{m}^{2}$
$\mathrm{~W} / \mathrm{m}^{2}$
$\mathrm{~m}$
$\mathrm{~kg}$
$\mathrm{~W} / \mathrm{m}^{2}$
$\mathrm{~m}^{2}$
$\mathrm{~K},{ }^{\circ} \mathrm{C}$
$\mathrm{m} / \mathrm{s}$
$\mathrm{m} / \mathrm{s}$
$\mathrm{m}$
-
$\mathrm{W} / \mathrm{m}^{2} \mathrm{~K}^{4}$
$\circ$
$\mathrm{W}$


$\varepsilon \quad$ emissivity

$\mu \quad$ dynamic viscosity

$\rho \quad$ density

$\lambda$ Thermal conductivity

$\eta \quad$ Efficiency

Subscripts

a air

ab absorber

amb ambient

cd conduction

cv convective

g glass

gr ground

in insulating material

ini insulating material inside

ino insulating material outside

$\mathrm{a}^{2} \quad$ Air passage 2

\section{Appendix}

\section{Appendix 1}

Heat transfer coefficient [19, 22].

$$
\begin{aligned}
& h_{r, s}=\sigma \varepsilon_{g}\left(T_{s}{ }^{2}+T_{u g o}{ }^{2}\right)\left(T_{s}+T_{u g o}\right) \\
& T_{s}=0,0552 * T_{a m}^{1,5} \\
& h_{c d, i}=\frac{\lambda_{i}}{e_{i}} \\
& h_{c v}=5,67+3,86 * v \\
& h_{c v, i}=\frac{N u_{i} * \lambda_{a}}{D H} \\
& h_{r, g r}=\sigma \varepsilon_{\text {in }} F_{g r_{-} i n}\left(T_{g r}{ }^{2}+T_{\text {ino }}{ }^{2}\right)\left(T_{g r}+T_{\text {ino }}\right) \\
& \mathrm{T}_{\mathrm{gr}}=\mathrm{T}_{\mathrm{amb}} \\
& 500<\operatorname{Re}_{i}<5000 \\
& N u_{i}=0,69 * \operatorname{Re}_{i}{ }^{0,514} * \operatorname{Pr}^{1 / 3}
\end{aligned}
$$

Other case $N u_{i}=0,021 * \operatorname{Re}_{i}{ }^{0,8} * \operatorname{Pr}^{1 / 3} *\left(\frac{\operatorname{Pr}\left(T_{a 1}\right)}{\operatorname{Pr}\left(T_{l g i}\right)}\right)^{0,43}$

$$
*\left(1+\left(\frac{D H}{\Delta X}\right)^{0,7}\right)
$$

for Rei $>7000 \operatorname{Re}_{i}=\frac{U * D H * \rho_{a, i}}{\mu_{a, i}}$

$$
\begin{aligned}
& \operatorname{Pr}=\frac{\mu_{a} * C p_{a}}{\lambda_{a}} \\
& D H=\frac{2 * d_{a 1} * l_{c}}{l_{c}+d_{a 1}}
\end{aligned}
$$

Appendix 2

Modeling of solar radiation [13].

$$
\begin{aligned}
& \mathrm{kg} / \mathrm{m} . \mathrm{s} \\
& \mathrm{kg} / \mathrm{m}^{3} \\
& \mathrm{~W} / \mathrm{m} \mathrm{K}^{\mathrm{K}} \\
& \%
\end{aligned}
$$

$\begin{array}{ll}\text { lgi } & \text { lower glass inside } \\ \text { lgo } & \text { lower glass outside } \\ \mathrm{r} & \text { radiative } \\ \mathrm{s} & \text { sky } \\ \text { a1 } & \text { air passage 1 } \\ \text { ugi } & \text { upper glass inside } \\ \text { ugo } & \text { upper glass outside } \\ \text { u1 } & \text { usefull passage 1 } \\ \text { u2 } & \text { usefull passage 2 } \\ \text { c } & \text { collector } \\ \text { re } & \text { refleted }\end{array}$

$$
\begin{aligned}
& I_{h}=I * \sin (h) I=I_{0} * a * \exp \left(\frac{-b}{\sin (h)}\right) \\
& \sin (h)=\cos (\varnothing) * \cos (\omega) * \cos (\delta)+\sin (\varnothing) * \sin (\delta) \\
& I_{d}=I_{0} * \sin (h) *\left[0.271-0.2939 * a * \exp \left(\frac{-b}{\sin (h)}\right)\right] \\
& G_{t-h}=I_{h}+I_{d} \\
& I_{0}=1367 *[1+0.034 * \cos (0.986 * J-2)] \\
& R_{b}=\frac{\cos (\theta)}{\sin (h)}, R_{c}=\frac{1+\cos (\beta)}{2}, R_{s}=\frac{1-\cos (\beta)}{2} \\
& I_{d_{s}}=\left(I_{d}+I * \sin (h)\right) * \operatorname{alb} * R_{s} \\
& \cos (\theta)=\sin (h) * \cos (\beta)+\cos (h) * \sin (\beta) \\
& \quad * \cos \left(\alpha_{s}-\alpha\right) \\
& G_{t}=I_{h} * R_{b}+I_{d} * R_{c}+I_{d_{s}}
\end{aligned}
$$

\section{References}

[1] Guemene Dountio, E., Njomo, D., Fouda, E., and Simo, A.: 'On the reliability of HELIOSAT method: A comparison with experimental data', Solar Energy, 2010, 84, (6), pp. 10471058.

[2] Jacek Jan Fiuk and Krzysztof Dutkowski, Experimental investigations on thermal efficiency of a prototype passive solar air collector with wavelike baffles. Solar Energy 2019, 188, pp. $495-506$

[3] Viorel Badescu, Iuliana Soriga, Adrian Ciocanea, Solar air collector performance in transient operation under radiative regimes with different levels of stability. Solar Energy 2019, 177, pp. 495-506.

[4] Jacek Leśny, Monika Panfil, Marek Urbaniak, Influence of irradiance and irradiation on characteristic parameters for a solar air collector prototype, Solar Energy, 2018, 164, pp. 224-230. 
[5] Fudholi, A., Sopian, K., Bakhtyar, B., Gabbasa, M., Othman, M. Y., and Ruslan, M. H.: 'Review of solar drying systems with air based solar collectors in Malaysia', Renewable and Sustainable Energy Reviews, 2015, 51, pp. 1191-1204.

[6] Vijaya Venkata Raman, S., Iniyan, S., and Goic, R.: 'A review of solar drying technologies', Renewable and Sustainable Energy Reviews, 2012, 16, (5), pp. 2652-2670.

[7] Tetang, F. A., Edoun, M., Chesneau, X., Kuitche, A., and Zeghmati, B.: 'Influence de l'intermittence sur le séchage solaire convectif indirect de la mangue Amélie'. Proc. 17è Journées Internationales de Thermique (JITH 2015) Marseille, France 2015, 6 p.

[8] Edoun, M., Kuitche, A., Marouzé, C., Giroux, F., and Kapseu, C.: 'Pratique du séchage artisanal de fruits et légumes dans le sud du Cameroun', Fruits, 2011, 66, (1), pp. 25-36.

[9] Tchinda, R., and Kaptouom, E.: 'Situation des energies nouvelles et renouvelables au Cameroun', Revue de l'Energie, 1999, (510), pp. 653-658.

[10] Kameni, N. M., Mempouo, B., Rene, T., Costa, Á. M., Orosa, J. A., Raminosoa, C. R. R., and Mamiharijaona, R.: 'Resource potential and energy efficiency in the buildings of Cameroon: A review', Renewable and Sustainable Energy Reviews, 2015, 50, pp. 835-846.

[11] Roberto Garay Martinez, Julen Astudillo Larraz, Performance assessment of façade integrated glazed air solar thermal collectors, Energy Procedia, 2017, 115, pp. 353-360.

[12] Tetang, F. A., Edoun, M., Chesneau, X., Kuitche, A., and Zeghmati, B.: 'Modélisation du rendement thermique d'un insolateur double vitrage et double passe dans un environnement tropical humide'. Proc. Energy, Materials, Applied Energetics and Pollution, ICEMAEO2018, Constantine, Algeria, 2018. pp 244-250.

[13] Oudjedi, S., Boubghal, A., Chaouch, W. B., Chergui, T., and Belhamri, A.: 'Etude théorique et expérimentale d'un capteur solaire à air destiné au séchage (Partie: 1)', Journal of Renewable Energies SMSTS, 2009, 8, pp. 237-248.

[14] Ihaddadene, N., Ihaddadene, R., and Mahdi, A.: 'Effect of distance between double glazing on the performance of a solar thermal collector', in Editor: 'Book Effect of distance between double glazing on the performance of a solar thermal collector', 2014, 5 p.

[15] Buker, M. S., and Riffat, S. B.: 'Building integrated solar thermal collectors - A review', Renewable and Sustainable Energy Reviews, 2015, 51, pp. 327-346.
[16] Nikolić, N., and Lukić, N.: 'Theoretical and experimental investigation of the thermal performance of a double exposure flat-plate solar collector', Solar Energy, 2015, 119, pp. 100113.

[17] Agbossou, K., Tetang, F., Boroze, T., N'wuitcha, K., Napo, K., and Zeghmati, B.: 'Theoretical and experimental study of thermal performance of flat plate air heating collector', International Journal of Science and Technology, 2016, 5, (10), pp. 473-490.

[18] Hu J. and Zhang G.: 'Performance improvement of solar air collector based on airflow reorganization: A review'. Applied Thermal Engineering. Volume 155, 5. 2019, pp 592-611.

[19] Dissa, A. O., Bathiebo, J., Kam, S., Savadogo, P. W., Desmorieux, H., and Koulidiati, J.: 'Modelling and experimental validation of thin layer indirect solar drying of mango slices', Renewable Energy, 2009, 34, (4), pp. 10001008 .

[20] Ong, K.: 'Thermal performance of solar air heaters: mathematical model and solution procedure', Solar energy, 1995, 55, (2), pp. 93-109.

[21] Ricci, M., Bocci, E., Michelangeli, E., Micangeli, A., Villarini, M., and Naso, V.: 'Experimental tests of solar collectors prototypes systems', Energy Procedia, 2015, 82, pp. 744-751.

[22] Belghit, A., Belahmidi, M., Bennis, A., Boutaleb, B. C., and Benet, S.: 'Etude numérique d'un séchoir solaire fonctionnant en convection forcée', Revue générale de thermique, 1997, 36, (11), pp. 837-850.

[23] Laux, P., Jäckel, G., Tingem, R. M., and Kunstmann, H.: 'Impact of climate change on agricultural productivity under rainfed conditions in Cameroon-A method to improve attainable crop yields by planting date adaptations', Agricultural and Forest Meteorology, 2010, 150, (9), pp. 1258-1271.

[24] Kareem, M. W., Habib, K., Sopian, K., and Irshad, K.: 'Performance Evaluation of a Novel Multi-pass Solar Air Heating Collector', Procedia Engineering, 2016, 148, pp. 638645 .

[25] Tetang, F. A.: 'Modélisation des transferts de chaleur et de matière lors du séchage intermittent des fruits à forte teneur en eau: Application à la mangue 'Amélie'. Thèse de Doctorat, Université de Ngaoundéré. 2018. 224 pages. 